\title{
Clinical Aspects of Physiology Teaching for Ergotherapists
}

\author{
Uliana Shalamay ${ }^{*}$, Nadiia Pobigun
}

\begin{abstract}
Ergotherapist - is the youngest specialty in medical practice of Ukraine. The aim of higher medical educational institutions is to formulate logical, clinical thinking and effective assimilation of medical knowledge to be used by ergotherapists-practitioners. One of the main tasks of an ergotherapist is to restore the body's functions that have been lost as a result of illness or injury, and to restore a person to a full social life (self-care, work, etc.). These specialists are working to restore the sensory and motor functions of the body, to develop new skills and abilities for the person to adapt to living in society. Achievement of the goal and performance of these tasks is impossible without knowledge of physiology, which provides the basis for the study of pathophysiology, pharmacology, cardiology, physiotherapy and other clinical disciplines. It improves the quality of study and helps to better acquire theoretical material, to master the skills of clinical physiology a competent approach in the organization of Physiology teaching.
\end{abstract}

Keywords

ergotherapists; clinical physiology; institutions of higher medical education

Ivano-Frankivsk National Medical University, Ivano-Frankivsk, Ukraine

*Corresponding author: fap12710@gmail.com

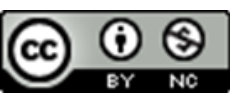

Copyright (C)Uliana Shalamay, Nadiia Pobigun, 2019

\section{Introduction}

One of the main tasks of the institutions of higher medical education of Ukraine is the qualitative training of future doctors, which would meet international standards. Its implementation is possible only with continuous improvement of the educational process, the use of new integrative forms and teaching methods of the disciplines (use of the case method, hybrid learning, the latest computer technologies, etc.) $[1,8]$. In such circumstances, future professionals will be able to obtain knowledge that they can effectively apply in practice.

Ergotherapist is one of the youngest specialties in the medical field, having been recently added to the occupational classification of Ukraine. Ergotherapists are healthcare professionals who treat the body as a whole, working on physical move- ments, taking into account the cognitive functions and emotional state of the patient $[6,7]$.

Modern methods of teaching in higher education institutions are aimed at formation of the comfortable relations between the teacher and the student and creating psychophysiological conditions in which the student feels his intellectual independence and efficiency [2, 5, 9]. During the learning process, students should be interested in pursuing a profession and strive for continuous selfimprovement. For this, the theory should be constantly reinforced by practice, even in theoretical departments $[4,10]$. The use of modern integrative technologies enables students to develop creativity, to acquire professional skills, to discover and to realize themselves in the future profession [3]. The requirements for the training of ergotherapists- 
practitioners should be directed not only to the assimilation of new information, but also to the formation of logical, clinical thinking.

\section{Discussion}

Physiology - is a theoretical science that studies the patterns of vital activity of a healthy organism under the influence of environmental factors at the level of molecules, cells, tissues, organs and functional systems. It is important for ergotherapists to study Anatomy, Physiology, Pathophysiology, Neurology, Psychology, etc. Physiology integrates with many basic disciplines, laying the foundations for the study of Pathophysiology, Pharmacology, Cardiology, Physiotherapy and other clinical disciplines.

The main task in the medical practice of the ergotherapist is to restore the functions of the human body that have been lost due to injury or illness. These experts are working to restore fine and gross motor skills after suffering a trauma. For example, an ergotherapist after the removal of a plaster splint of a patient (as a result of a bone fracture) must draw up an individual rehabilitation plan aimed at restoration of all lost functions (fine motor skills, tactile and temperature sensitivity, etc.). This will not be possible without knowledge of Physiology, namely, the mechanism of nerve impulse transmission, muscle contraction, and the functionality of the somatic-sensory system. In spinal injuries, the task of the ergotherapist is not only to restore the musculoskeletal functions of the body, but also in the psychological desire to target the patient for a positive result.

An important component in the work of ergotherapists is the development of new skills in patients and the fulfillment of certain tasks in their personal lives, the adaptation of the patient to living in society. For example, children with deficits of social interaction and communication (autistic ones) need to be taught to look after themselves (to stand up, to carry out morning hygiene, to dress, etc.), i.e., to develop conditioned reflexes and to develop the musculoskeletal and sensory system.

The Department of Physiology of Ivano-Frankivsk National Medical University is constantly work- ing on improvement of the modern educationalmethodological process, which contributes to improvement of the quality of theoretical preparation for practical classes and the formation of qualitative knowledge, skills and abilities of the student. For this purpose, each practical training consists of two parts (theoretical and practical). In order to effectively transform theoretical knowledge into clinical thinking, students in the practical part, using the methods of observation, experiment or simulation, study and consolidate the studied physiological processes. These works for students are interesting, because they allow them to observe the results and independently influence the functioning of the body. Thus, students acquire the skills of measuring blood pressure, pulse, shifting visual acuity, hearing, recording functional indicators (they perform electrocardiography, electroencephalography, spirometry, picfluometry, etc.), determine blood groups and hemoglobin level in the capillary blood. In the study of somato-sensory sensitivity, the students learn to determine the tactile sensitivity of the skin (using Weber's compass), cold and thermal sensitivity. Using a neurological hammer, the tendon reflexes and the functions of the spinal cord are examined. During the study of the types of higher nervous activity, students learn to determine one-onone the peculiarities of a person's character using the method of Eysenck, to predict the behavior of the patient, since the program of further rehabilitation will depend on the peculiarities of the patient's character. Based on the obtained results, students give a vast answer regarding the interpretation of indicators.

Another interesting form of work - is modeling the clinical situation. For example, the study of the adaptation of the body to physical activity, which is used to evaluate the recovery of cardiovascular function after a disease. Students are divided into pairs into two groups, one is ergotherapist and the other is a patient. The doctor evaluates the patient's condition (hemodynamics indices: blood pressure and pulse rate, etc.) and addresses the possibility of physical exertion, their intensity. After physical exertion, blood pressure and pulse are measured every minute until full recovery, and the type of 
body's response to physical exertion is evaluated. The role of the teacher in the simulation of the clinical situation is to control the correctness of the experiment, compliance with all the requirements of the experiment, safety and guidance of students in the most rational explanation of the obtained results.

Another modern method that allows you to effectively digest theoretical material is the use of computer technologies. At the Department of Physiology, each study room is equipped with a television where you can watch videos that reflect the course of physiological processes. A new form of learning is a computer game in which a student virtually enters the human body and sees that he abstractly imagines as he understands the material learned. The computer game gives a clear idea of the functioning of organs and different systems. Thus, when entering, for example, into the stomach, the student must choose enzymes under the action of which the digestion of proteins, fats or carbohydrates occurs and the mechanisms of their absorption. Computer games can serve as both an educational and a controlling element in the study process.

\section{Conclusions}

A competent approach in the organization of Physiology teaching to ergotherapists improves the quality of study and the use of practical skills in further medical practice. Performance of various experiments by students helps to better understand theoretical material, to develop clinical thinking.

\section{References}

[1] Huranych TV. The use of case methods during the study of human physiology. Prykarpatsky visnyk NTSh. Pulse. 2016; 4(36):168-171.

[2] Hurevych RS, Kademiya MYu, Umanets VO. Innovative technologies in higher educational institutions. Modern information technologies and innovative educational methods in the training of specialists: methodology, theory, experience, problems. 2018;51:11-15.
DOI: https://doi.org/10.31652/ 2412-1142-2018-51-11-15

[3] Komplichenko OO, Tsvetkova OO. Use of interactive methods in the educational process and final control of students' knowledge. Information technologies in education, science and production. 2013;3(4):178-186.

[4] Kulayets NM. The use of modern teaching methods and innovative technologies in the educational process. Prykarpatsky visnyk NTSh. Pulse. 2016;4(36):172-178.

[5] Kurovska VO. Directions for improvement of the teaching of Physiology. Medychna osvita. 2013;1:45-47.

[6] Mazepa MM, Vovkanych AS, Tyravska OI, Tymchuk-Skoropad KA, Tsizh LM. Foreign experience in teaching ergotherapy. Visnyk Zaporizkoho natsionalnoho universytetu. 2017;1:136-143.

[7] Pustovoy BA, Pustovoy KB. Modern views of ergotherapy Physical rehabilitation and recreational technologies. 2017; 1:65-69.

[8] Senchenko VO, Shestopal OV, Nasonova NA. Implementation of innovative technology in education: the challenge of the XXI century, problems and prospects. Modern informational technologies and innovative teaching methods in the training of specialists: methodology, theory, experience, problems. 2018;51: 25-28. DOI: https://doi.org/10.31652/ 2412-1142-2018-51-25-28

[9] Stinska VV. Teaching methods in high school. Ivano Frankivsk. 2016; 65.

[10] Tuchak OI. Methods of increasing the efficiency of Physiology teaching to medical students. Visnyk problem biolohiyi i medytsyny. 2015; 2(4.121):53-55. 
Received: $2019-12-13$

Revised: 2019-12-18

Accepted: 2019-12-18 